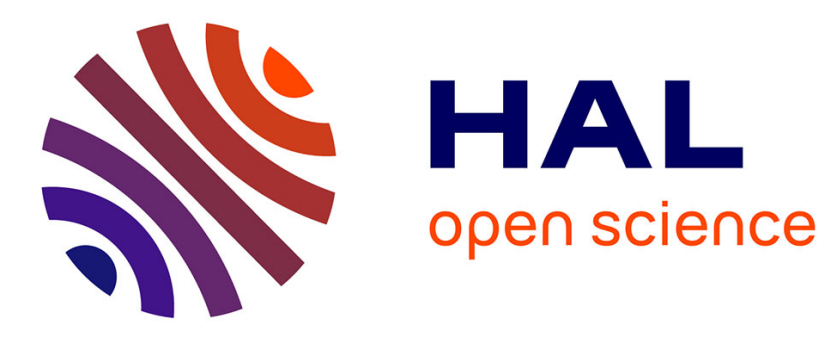

\title{
Late-stage Rh(II)-catalyzed Nitrene Transfer for the Synthesis of Guaianolide Analogs with Enhanced Antiproliferative Activity
}

Sebastián J Castro, José M. Padrón, Benjamin Darses, Viviana E Nicotra, Philippe Dauban

\section{To cite this version:}

Sebastián J Castro, José M. Padrón, Benjamin Darses, Viviana E Nicotra, Philippe Dauban. Latestage Rh(II)-catalyzed Nitrene Transfer for the Synthesis of Guaianolide Analogs with Enhanced Antiproliferative Activity. European Journal of Organic Chemistry, 2021, 2021 (12), pp.1859-1863. 10.1002/ejoc.202100074 . hal-03344899

\author{
HAL Id: hal-03344899 \\ https://hal.science/hal-03344899
}

Submitted on 15 Sep 2021

HAL is a multi-disciplinary open access archive for the deposit and dissemination of scientific research documents, whether they are published or not. The documents may come from teaching and research institutions in France or abroad, or from public or private research centers.
L'archive ouverte pluridisciplinaire HAL, est destinée au dépôt et à la diffusion de documents scientifiques de niveau recherche, publiés ou non, émanant des établissements d'enseignement et de recherche français ou étrangers, des laboratoires publics ou privés. 


\title{
Late-stage Rh(II)-catalyzed Nitrene Transfer for the Synthesis of Guaianolide Analogues with Enhanced Antiproliferative Activity.
}

\author{
Sebastián J. Castro, *a,b,d José M. Padrón, ${ }^{c}$ Benjamin Darses, ${ }^{a, e}$ Viviana E. Nicotra, ${ }^{*, b}$ \\ and Philippe Dauban*,a
}

[a] Dr. S. J. Castro, Dr. B. Darses, Dr. P. Dauban Institut de Chimie des Substances Naturelles, CNRS UPR 2301, Univ. Paris-Sud, Université Paris-Saclay, av. de la Terrasse, 91198 Gif-sur-Yvette, (France).

E-mail: philippe.dauban@cnrs.fr

av. de la Terrasse, 91198 Gif-sur-Yvette, (France).

https://icsn.cnrs.fr/cv/dauban

[b] Dr. S. J. Castro, Prof. Dr. Viviana E. Nicotra

Facultad de Ciencias Químicas, Instituto Multidisciplinario de Biología Vegetal (IMBIV-CONICET),

Universidad Nacional de Córdoba, Casilla de Correo 495, 5000 Córdoba, (Argentina).

E-mails : scastro@unc.edu.ar ; vnicotra@unc.edu.ar

http://organica.fcq.unc.edu.ar/lineas-de-investigacion/

[c] Prof. Dr. J. M. Padrón

BioLab, Instituto Universitario de Bio-Orgánica “Antonio González” (IUBO-AG), Universidad de La

Laguna, C/Astrofísico Francisco Sánchez 2, 38206 La Laguna, (Spain).

[d] Present address: Facultad de Ciencias Químicas, Instituto Multidisciplinario de Biología Vegetal (IMBIVCONICET), Universidad Nacional de Córdoba, Casilla de Correo 495, 5000 Córdoba, (Argentina).

[e] Present address: Univ. Grenoble Alpes, CNRS, DCM, 38000 Grenoble (France).

\begin{abstract}
A set of new guaianolide derivatives (1-9) was obtained from Ludartin, Achalensolide and 11,13Dihydroachalensolide by application of catalytic nitrene transfer reactions. Intermolecular nitrene $\mathrm{C}\left(\mathrm{sp}^{3}\right)-\mathrm{H}$ insertions led to the amination of $\mathrm{C}-1, \mathrm{C}-2$ and $\mathrm{C}-10$ positions, while alkene aziridination was also observed under these reaction conditions. The antiproliferative activity of natural compounds and their derivatives was evaluated against a panel of human solid tumour cell lines. The results show that an increase in the biological activity was observed following amination at the C-2 position of Ludartin, thereby demonstrating the interest of late-stage $\mathrm{C}-\mathrm{H}$ amination to improve the bioactivity of natural products.
\end{abstract}




\section{Main text}

The search for new bioactive compounds derived from natural products represents a successful strategy in drug discovery programs. ${ }^{[1]}$ The derivatizations generally rely on functional group transformations, whereas modifications of $\mathrm{C}-\mathrm{H}$ bonds were long neglected. However, functionalization of $\mathrm{C}-\mathrm{H}$ bonds offers invaluable opportunities to reach a new molecular diversity. The last decade has witnessed the emergence of $\mathrm{C}-\mathrm{H}$ activation reactions ${ }^{[2]}$ that are now applied to complex natural compounds. The socalled late-stage $\mathrm{C}-\mathrm{H}$ functionalization reactions are helpful to reach underexplored regions of the biologically relevant chemical space, ${ }^{[3]}$ and to tune the pharmaco-dynamic and -kinetic properties of bioactive compounds. ${ }^{[4]}$

Among the variety of $\mathrm{C}-\mathrm{H}$ bond functionalization reactions, those that install a nitrogen functional group stand out. ${ }^{[5]}$ Indeed, $80 \%$ of small-molecule drugs contain at least one nitrogen atom. ${ }^{[6]}$ Moreover, nitrogen-containing functional groups are helpful to tune both the activity and the bioavailability of a bioactive compound. ${ }^{[7]}$ Hence, the introduction of a new $\mathrm{C}-\mathrm{N}$ bond in a single step is a challenge with relevant application in medicinal chemistry. In this context, catalytic iodine(III)mediated nitrene transfer reactions, such as $\mathrm{C}\left(\mathrm{sp}^{3}\right)-\mathrm{H}$ amination and alkene aziridination, have emerged as new synthetic tools for the preparation of potentially bioactive nitrogen-containing molecules. ${ }^{[5,8]}$

Sesquiterpene lactones are important bioactive secondary metabolites found in several angiosperm plant families. ${ }^{[9]}$ Most of these products bear alkylating groups, such as an $\alpha$-methylene- $\gamma$-lactone moiety, that are responsible for their biological activity. ${ }^{[10]}$ Lipophilicity, molecular geometry, and electronic characteristics are other factors that may influence their biological response. ${ }^{[1]}$ With the aim to tune their bioactivity, various sesquiterpene lactones derivatives have been prepared particularly via the transformation of the exocyclic double bond. ${ }^{[12]}$ Thus, based on this observation and our expertise in nitrene chemistry, ${ }^{[13]}$ we envisaged to derivatize sesquiterpene lactones by application of catalytic nitrene transfer with the main objective of functionalizing new centers thereby accessing a new chemical space. Such changes was likely to influence the antiproliferative activities of the parent compounds. In this communication, we present the results of our investigations on natural guaianolides (Figure 1).

\section{Figure 1.}

Of particular interest for the present work were sesquiterpene lactones obtained from Stevia species. The cytotoxic Ludartin ${ }^{[14]}$ can be isolated from Stevia yaconensis var. subeglandulosa Hieron. ${ }^{[15]}$ On the 
other hand, Achalensolide and 11,13-Dihydroachalensolide have been isolated from the aerial parts of Stevia achalensis Hieron., an Argentinian endemic Asteraceae species. ${ }^{[16]}$ The amination of these three natural guaianolides was investigated by application of protocols involving the use of $\mathrm{Rh}_{2}(\mathrm{esp})_{2}(\mathrm{esp}=$ $\alpha, \alpha, \alpha^{\prime}, \alpha^{\prime}$-tetramethyl-1,3-benzenedipropionic acid) as the catalyst, and two different sulfamates as nitrene precursors: trichloroethoxysulfonamide $\left(\mathrm{TcesNH}_{2}\right)$ or phenylsulfamate $\left(\mathrm{PhsNH}_{2}\right){ }^{[17]}$ These conditions that involve the in situ formation of an iminoiodinane, and then a metallanitrene, are among the most efficient for catalytic intermolecular nitrene transfers. ${ }^{[18]}$ Moreover, the regioselectivity of the $\mathrm{C}-\mathrm{H}$ amination reaction can be controlled by the nature of the sulfamate. ${ }^{[19]}$

We first investigated the application of catalytic intermolecular nitrene insertion reactions using the sulfamate $\mathrm{TcesNH}_{2}$ as the nitrene source (Scheme 1). It should be pointed out that the guaianolide starting material was the limiting component in all the reactions that occur with a good mass balance. Though the yields are low, all the reactions only afford the aminated products and recovered starting materials.

Starting from Ludartin, the reaction afforded compound $1(25 \%)$ that revealed a molecular formula of $\mathrm{C}_{17} \mathrm{H}_{20} \mathrm{Cl}_{3} \mathrm{NO}_{6} \mathrm{~S}$ by HRESIMS. The NMR spectroscopic data suggested the presence of a new $\mathrm{C}-\mathrm{N}$ bond at C-2 [ $\left.\delta_{\mathrm{H}} 4.60(\mathrm{~d}, J=6.10 \mathrm{~Hz}, \mathrm{H}-2), \delta_{\mathrm{C}} 57.2(\mathrm{C}-2)\right]$ corresponding to the introduction of a [2,2,2(trichloroethoxy)sulfonyl]amino group. The location of the $\mathrm{C}-\mathrm{N}$ bond was confirmed by the HMBC correlation between the signal of H-2 and C-1 ( $\delta$ 134.6), C-3 ( $\delta 64.3), \mathrm{C}-4(\delta 66.8)$, and C-10 $(\delta 143.8)$ (see Figure S2 Supporting Information). The $\beta$ orientation of the $\mathrm{C}-\mathrm{N}$ bond was proposed based on the NOE observed between NH $\left(\delta_{\mathrm{H}} 5.30\right)$ and H-6 $\left(\delta_{\mathrm{H}} 3.62\right)$, possible only under these conditions (see Figure S4 Supporting Information). We propose that the complete diastereoselectivity may result from the presence of the epoxy group at C-3 and C-4 positions. ${ }^{[21]}$

\section{Scheme 1.}

The same reaction conditions were applied to Achalensolide affording compounds $2(7 \%)$ and 3 (26\%). Not surprisingly, the amination of the C-2 position was not observed as the $\mathrm{C}-\mathrm{H}$ bond is deactivated by the adjacent electron-withdrawing carbonyl group. Compound 2 revealed a molecular formula of $\mathrm{C}_{17} \mathrm{H}_{20} \mathrm{Cl}_{3} \mathrm{NO}_{6} \mathrm{~S}$ by HRESIMS. Inspection of the 1D and 2D NMR spectroscopic data indicated that compound 2 possesses an aziridine function involving C-11 $\left(\delta_{C} 49.6\right)$ and C-13 $\left(\delta_{C} 36.6\right)$. The ${ }^{1} \mathrm{H}$ NMR signals at $\delta 3.10(\mathrm{H}-13 \mathrm{a})$ and $\delta 2.99(\mathrm{H}-13 \mathrm{~b})$ and the absence of resonances corresponding to the exocyclic double bond are in good agreement with the presence of an aziridine function at this position. The orientation of the aziridine was proposed based on the NOE observed between H-13a $(\delta 3.10)$ and H-6a ( $\delta 2.88)$, (see Figure S7 Supporting Information). 
Compound 3 exhibited a molecular formula of $\mathrm{C}_{22} \mathrm{H}_{30} \mathrm{Cl}_{3} \mathrm{NO}_{8} \mathrm{~S}$ by HRESIMS. The inspection of NMR spectroscopic data clearly showed that compound $\mathbf{3}$ results from the aziridine ring opening by pivaloic acid released from the iodine(III) oxidant, as previously reported by one of us. ${ }^{[22]}$ The aziridine opening at $\mathrm{C}-13$ was proposed based on the appearance of the signals corresponding to the pivaloyloxy group [ $\delta_{\mathrm{H}} 1.24\left(\mathrm{~s}, \mathrm{H}_{3}-3\right.$ ''), $\delta_{\mathrm{C}} 177.4\left(\mathrm{C}-1\right.$ ''), $\delta_{\mathrm{C}} 39.0\left(\mathrm{C}-2\right.$ ''), and $\delta_{\mathrm{C}} 27.2$ (C-3' ')] and the upfield shifts of the $\mathrm{CH}_{2}-13$ methylene signals from $\delta_{\mathrm{C}} 36.6, \delta_{\mathrm{H}} 3.10$, and $\delta_{\mathrm{H}} 2.99$ for compound 2 to $\delta_{\mathrm{C}} 64.3, \delta_{\mathrm{H}} 4.53$, and $\delta_{\mathrm{H}}$ 4.39 for compound 3. The pattern of substitution at C-11 was confirmed through the correlation observed in the HMBC spectrum between $\mathrm{H}_{2}-13$ and $\mathrm{C}-12(\delta$ 172.7) and C-1' $(\delta 177.4)$ (see Figure S11 Supporting Information). In turn, NOE was observed between H-13a and H-6 signals confirming the $\beta$ orientation for the pivaloyloxy substituent (see Figure S12 Supporting Information).

The amination reaction of 11,13-Dihydroachalensolide under these conditions afforded the sole compound 4 with 5\% yield. Analysis of the NMR spectra showed the disappearance of one methine from the substrate and the presence of a quaternary carbon at $\delta 70.1$ assigned to the $\mathrm{C}-1$ position. The location of the aminated substituent was confirmed by the HMBC correlation between the signal of C-1 and $\mathrm{H}_{2}-2(\delta 2.84$ and $\delta 2.34), \mathrm{H}_{2}-6(\delta 2.91$ and $\delta 2.74), \mathrm{H}_{2}-9$ ( $\delta 1.68$ and 1.32), $\mathrm{H}-10(\delta 1.88), \mathrm{H}_{3}-14(\delta$ 1.21 ), and $\mathrm{H}_{3}-15$ ( $\delta 1.79$ ) (see Figure S16 Supporting Information). As previously observed in the latestage $\mathrm{C}\left(\mathrm{sp}^{3}\right)-\mathrm{H}$ amination of natural products displaying tertiary centers, ${ }^{[17 \mathrm{~b}, \mathrm{c}]}$ the reaction takes place stereospecifically at the C-1 tertiary position delivering product 4 with retention of configuration.

We then applied the same reaction conditions with a different nitrene precursor, $\mathrm{PhsNH}_{2}$, known to favor the amination of tertiary $\mathrm{C}-\mathrm{H}$ bonds (Scheme 2). ${ }^{[17 \mathrm{c}, 20]}$ All the reactions occur with a good mass balance affording only the aminated products and recovered starting materials. Ludartin afforded compound $5(36 \%)$ that revealed a molecular formula a molecular formula of $\mathrm{C}_{21} \mathrm{H}_{23} \mathrm{NO}_{6} \mathrm{~S}$ by HRESIMS. The similarity in the ${ }^{1} \mathrm{H}$ and ${ }^{13} \mathrm{C}$ NMR chemical shifts of compounds $\mathbf{5}$ and $\mathbf{1}$ indicated that they possess the same skeleton substitution pattern, and stereochemistry. The only differences between $\mathbf{5}$ and $\mathbf{1}$ were the signals corresponding to the phenylsulfonyl substituent. In addition to product $\mathbf{5}$, traces of a compound that revealed to be the aziridine $\mathbf{6}$, were also isolated.

\section{Scheme 2.}

For Achalensolide, compound 7 (10\%) and compound 8 (16\%) were obtained. As previously proposed in the case of compound 3, 7 is likely the result of an alkene aziridination at the $\mathrm{C}-11 / \mathrm{C}-13$ double bond followed by a ring opening by pivaloic acid. The same characteristic signals as those described for 3 were observed: the absence of the signals corresponding to the exocyclic double bond, the presence of the signals of the pivaloyloxy group, the chemical shift of the $\mathrm{CH}_{2}-13$, the $\mathrm{HMBC}$ correlations between 
$\mathrm{H}_{2}-13$ and C-12 at $\delta 172.5$ and C-1', at $\delta$ 177.7, and the NOE observed between H-13b and $\mathrm{H}_{2}-6$ at $\delta$ 3.09 and $\delta 2.49$ (see Figure S27 Supporting Information). Compound 8 showed a molecular formula of $\mathrm{C}_{21} \mathrm{H}_{23} \mathrm{NO}_{6} \mathrm{~S}$ by HRESIMS. NMR data analysis suggested the presence of the aminated substituent at C10 position by the following evidence: the disappearance of the signal corresponding to the methine group at $\mathrm{C}-10$, the change in the multiplicity of the $\mathrm{H}_{3}-14\left(\delta_{\mathrm{H}} 1.13\right)$ from doublet to singlet, and the presence of a signal corresponding to a quaternary carbon at $\delta 60.5$.

Compound 9 (17\%) derived from 11,13-Dihydroachalensolide under the same reacting conditions. The HRESIMS of 9 showed a molecular ion corresponding to a molecular formula of $\mathrm{C}_{21} \mathrm{H}_{25} \mathrm{NO}_{6} \mathrm{~S}$. Its $1 \mathrm{D}$ and 2D NMR spectroscopic data indicated that compound $\mathbf{9}$ was closely related to compound $\mathbf{4}$, indicating the presence of the aminated substituent at C-1 (Table 2). The only differences between 9 and 4 were the signals corresponding to the phenylsulfonyl substituent. As in the case of $\mathbf{4}$, the reaction proceeded stereospecifically with retention of configuration at the tertiary site.

Considering the antiproliferative activity shown by several sesquiterpene lactones, ${ }^{[22]}$ Ludartin, Achalensolide, 11,13-Dihydroachalensolide, and their derivatives (1,3-9) were evaluated towards six representative human solid tumor cell lines (A549, HBL-100, HeLa, SW1573, T-47D, and WiDr). The amount of derivative $\mathbf{2}$ obtained was insufficient to carry out the bioactivity tests. The antiproliferative effect was studied using the SRB assay. ${ }^{[23]}$ Table 1 shows the results expressed as 50\% growth inhibition $\left(\mathrm{GI}_{50}\right)$ values. ${ }^{[24]}$ The anticancer drug cisplatin was used as a reference compound.

\section{Table 1.}

Viewed as a whole, these results allowed classifying the compounds into three groups. A first group, comprising Achalensolide and Ludartin derivatives 1 and 5, caused significant growth inhibition $\left(\mathrm{GI}_{50}\right.$ $<10 \mu \mathrm{M}$ in all cell lines). The second set of compounds, including Ludartin and derivatives 3, 6, and 8 exhibited moderate activity ( $\mathrm{GI}_{50}$ in the $10-40 \mu \mathrm{M}$ range). The third group, containing 11,13dihydroachalensolide and derivatives 4, 7, and 9 failed to show growth inhibition. Although 8 is slightly less active than $\mathbf{1}$ and $\mathbf{5}$, the results tend to indicate that the presence of an exocyclic methylene group conjugated with the $\gamma$-lactone is crucial for the activity, confirming the role of this motif in the antiproliferative response. This is in agreement with previous reports where the modification of this functionality resulted in the loss of the bioactivity. ${ }^{[25]}$

A significant increase in potency was detected in the aminated derivatives $\mathbf{1}$ and $\mathbf{5}$ of Ludartin. The substitution at C-2 position led to the generation of compounds more potent than their precursor and even somewhat more active than the cisplatin positive control. However, with respect to Achalensolide, the introduction of the same substituents at C-10 did not show a significant change in the 
antiproliferative activity. These results confirm that the introduction of a nitrogeneous functional group can positively contribute to the bioactivity, however, its impact depends on its position. The most potent compounds Achalensolide, $\mathbf{1}$ and $\mathbf{5}$ were selected as leads. Thus, they were tested against the human fibroblast cell line BJ-hTERT to determine their selectivity. The results indicate that the most potent compounds are at least 10 times more selective toward any of the rested tumor cell lines.

Next, we studied the ability of the most active compounds to act as substrates for P-glycoprotein (P-gp), which is known to induce drug resistance in tumor cells by extruding toxins and xenobiotics out of the cell. ${ }^{[26]}$ Achalensolide, $\mathbf{1}$ and $\mathbf{5}$ were evaluated for their possible interaction with P-gp. For this purpose, we tested the compounds against a wild-type cell line (SW1573) and its P-gp overexpressing variant $(\mathrm{SW} 1573 / \mathrm{Pgp}),{ }^{[27]}$ in the presence or the absence of the known P-gp inhibitor verapamil $(10 \mu \mathrm{M}) .{ }^{[28]} \mathrm{As}$ reference drugs for this assay, we used the microtubule interacting drugs Paclitaxel and Vinblastine, which are known substrates for P-gp. The results, given as resistance factor (Rf), i.e. the ratio of $\mathrm{GI}_{50}$ values in the P-gp overexpressing line to those in the wild type cell line, are shown in Table 2. Achalensolide, compounds 1 and 5 all show low Rf values, denoting no effect of P-gp on their biological activity. Overall, the results indicate that the test compounds are not substrates for P-gp.

\section{Table 2.}

In conclusion, this exploratory study highlights that late-stage $\mathrm{C}-\mathrm{H}$ functionalization reactions are useful tools to tune the bioactivity of natural products. Application of rhodium-catalyzed nitrogen-atom transfer reactions allowed us to explore a new biologically relevant chemical space with the isolation of 9 new derivatives from naturally occurring sesquiterpene lactones. These reactions proved to be useful for accessing, in one step, functionalized derivatives at positions tedious to modify by conventional synthetic methods. Particularly, tertiary and allylic positions were preferentially aminated, but the study also underscores the influence of the nitrene precursors on the chemoselectivity of the $\mathrm{C}-\mathrm{H}$ amination reaction. Importantly, this strategy has allowed the isolation of $\mathrm{C}-\mathrm{H}$ aminated products that display improved antiproliferative activities when compared to those of the parent natural product. The combination of an interesting antiproliferative activity on cancer cell lines with the absence of extrusion by P-gp could make the evaluated molecules promising starting points for further development. Work is in progress to this end as well as to apply catalytic nitrene transfers to other natural products. 


\section{Acknowledgements}

This work was supported by grants from CONICET (PIP 2015-2017, Res. 0111/16) and SeCyT-UNC (Res. 411/18) and the French National Research Agency (program ANR-15-CE29-0014-01). S.J.C. thanks CONICET (Argentina) for a fellowship. We wish to thank G. Bonetto for NMR assistance and the Institut de Chimie des Substances Naturelles for the support. J.M.P. thanks the Spanish Government for financial support through project PGC2018-094503-B-C22 (MCIU/AEI/FEDER, UE).

\section{References}

[1] D. J. Newman, G. M. Cragg, J. Nat. Prod. 2020, 83, 770-803.

[2] a) K. Godula, D. Sames, Science 2006, 312, 67-72; b) R. Jazzar, J. Hitce, A. Renaudat, J. Sofack-Kreutzer, O. Baudoin, Chem. Eur. J. 2010, 16, 2654-2672; c) H. M. L. Davies, J. Du Bois, J.-Q. Yu, Chem. Soc. Rev. 2011, 40, 1855-1856; d) J. Yamaguchi; A. D. Yamaguchi, K. Itami, Angew. Chem. Int. Ed. 2012, 51, 8960-9009; Angew. Chem. 2012, 124, 9092-9142; e) J. F. Hartwig, J. Am. Chem. Soc. 2016, 138, 2-24; f) J. C. K. Chu, T. Rovis, Angew. Chem. Int. Ed. 2018, 57, 62-101; Angew. Chem. 2018, 130, 64-105.

[3] a) R. R. Karimov, J. F. Hartwig, Angew. Chem. Int. Ed. 2018, 57, 4234-4241; Angew. Chem. 2018, 130, 4309-4317; b) C. R. Shugrue, S. J. Miller, Chem. Rev. 2017, 117, 11894-11951; c) B. Hong, T. Luo, X. Lei, ACS Cent. Sci. 2020, 6, 622-635.

[4] a) c) T. Cernak, K. D. Dykstra, S. Tyagarajan, P. Vachal, S. W. Krska, Chem. Soc. Rev. 2016, 45, 546-576; b) M. Moir, J. J. Danon, T. A. Reekie, M. Kassiou Expert Opin. Drug Discov. 2019, 14, 1137-1149.

[5] a) F. Collet, R. H. Dodd, P. Dauban, Chem. Commun. 2009, 5061-5074; b) D. N. Zalatan, J. Du Bois, Top. Curr. Chem. 2010, 292, 347-378; c) Y. Park, Y. Kim, S. Chang, Chem. Rev. 2017, 117, 9247-9301; d) H. Hayashi, T. Uchida, Eur. J. Org. Chem. 2020, 909-916.

[6] a) E. Vitaku, D. T. Smith, J. T. Njardarson, J. Med. Chem. 2014, 57, 10257-10274; b) N. Kerru, L. Gummidi, S. Maddila, K. K. Gangu, S. B. Jonnalagadda, Molecules 2020, 25, 1909-1950.

[7] For a relevant example showcasing the influence of adding a nitrogen functional group on the bioactivity, see: J. N. E. Sears, D. L. Boger, Acc. Chem. Res. 2015, 48, 653-662.

[8] For reviews, see: a) J. W. W. Chang, T. M. U. Ton, P. W. H. Chan, Chem. Rec. 2011, 11, 331-357; b) J. L. Roizen, M. E. Harvey, J. Du Bois, Acc. Chem. Res. 2012, 45, 911-922; c) J. Buendia, G. Grelier, P. Dauban, Adv. Organomet. Chem. 2015, 64, 77-118; d) J. M. Alderson, J. R. Corbin, J. M. Schomaker, Acc. Chem. Res. 2017, 50, 2147-2158; e) D. Hazelard, P. A. Nocquet, P. Compain, Org. Chem. Front. 2017, 4, 2500-2521.For recent examples of applications of catalytic nitrene transfers to the late-stage amination of natural products, see: f) J. Li, J. S. Cisar, C.-Y. Zhou, B. Vera, H. Williams, A. D. Rodríguez, B. F. Cravatt, D. Romo, Nat. Chem. 2013, 5, 510-517; f) T. Pitterna, J. Cassayre, O. F. Hüter, P. M. J. Jung, P. Maienfisch, F. M. Kessaby, L. Quaranta, H. Tobler, Bioorg. Med. Chem. 2009, 17, 4085-4095;

[9] V. P. Sülsen, V. S. Martino, Sesquiterpene Lactones: Advances in their Chemistry and Biological Aspects; Springer International Publishing AG, 2018.

[10] M. Chadwik, H. Trewin, F. Gawthrop, C. Wagstaff, Int. J. Mol. Sci. 2013, 14, 12780-12805.

[11] A. Ghantous, H. Gali-Muhtasib, H. Vuorela, N. A. Saliba, N. Darwiche, Drug Discov. Today 2010, 15, 668-678.

[12] A. Santana, J. M. G. Molinillo, F. A. Macías, Eur. J. Org. Chem. 2015, 2093-2110. 
[13] a) B. Darses, R. Rodrigues, L. Neuville, M. Mazurais, P. Dauban, Chem. Commun. 2017, 53, 493-508; b) M. I. Lapuh, A. Dana, P. H. Di Chenna, B. Darses, F. J. Durán, P. Dauban Org. Biomol. Chem. 2019, 17, 4736-4746.

[14] a) S. H. Lone, K. A. Bhat, S. Rehman, R. Majeed, A. Hamid, M. A. Khuroo, Bioorg. Med. Chem. Lett. 2013, 23, 4931-4934. For other reported biological activities, see: b) O. S. Giordano, E. Guerreiro, M. J. Pestchanker, J. Guzman, D. Pastor, T. Guardia, J. Nat. Prod. 1990, 53, 803-809; c) J. G. Blanco, R. R. Gil, C. I. Alvarez, L. C. Patrito, S. Genti-Raimondi, A. Flury, FEBS Lett. 1997, 409, 396-400.

[15] V. E. Sosa, J. C. Oberti, R. R. Gil, E. A. Rúveda, V. L. Goedken, A. B. Gutiérrez, W. Herz, Phytochemistry, 1989, 28, 1925-1929.

[16] J. C. Oberti, V. E. Sosa, W. Herz, J. S. Prasad, V. L. Goedken, J. Org. Chem. 1983, 48, 4038-4043.

[17] a) K. W. Fiori, J. Du Bois, J. Am. Chem. Soc. 2007, 129, 562-568; b) J. L. Roizen, D. N. Zalatan, J. Du Bois, Angew. Chem. Int. Ed. 2013, 52, 11343-11346; Angew. Chem. 2013, 125, 11553-11556; c) N. D. Chiappini, J. B. C. Mack, J. Du Bois, Angew. Chem. Int. Ed. 2018, 57, 4956-4959; Angew. Chem. 2018, $130,5050-5053$.

[18] Sulfonimidamides in combination with chiral rhodium(II) catalysts are also highly efficient reagents in intermolecular $\mathrm{C}\left(\mathrm{sp}^{3}\right)-\mathrm{H}$ amination, however, their application to the amination of guaianolide derivatives did not prove successful. For examples of catalytic amination with sulfonimidamides, see: a) C. Liang, F. Collet, R. Robert-Peillard, P. Müller, R. H. Dodd, P. Dauban, J. Am. Chem. Soc. 2008, 130, 343-350. b) C. Lescot, B. Darses, F. Collet, P. Retailleau, P. Dauban, J. Org. Chem. 2012, 77, 7232-7240.

[19] E. N. Bess, R. J. DeLuca, D. J. Tindall, M. S. Oderinde, J. L. Roizen, J. Du Bois, M. S. Sigman, J. Am. Chem. Soc. 2014, 136, 5783-5789.

[20] Lone et al. proposed a similar justification to account for the facial selection observed during the epoxidation of the more distant C-1/C-10 double bond of ludartin. See: S. H. Lone, K. A. Bhat, F. A. Malik, M. A. Khuroo, Planta Med. Int. Open. 2016, 3, e51-e54. Moreover, the preferred amination of the $\beta$-face might also result from a beneficial hyperconjugative effect from the neighboring $\pi$-system, the a$\mathrm{C}-\mathrm{H}$ bond being less reactive because it almost lies in the plane of the double bond.

[21] a) N. Gigant, G. Dequirez, P. Retailleau, I. Gillaizeau, P. Dauban, Chem. Eur. J. 2012, 18, 90-94; b) G. Dequirez, J. Ciesielski, P. Retailleau, P. Dauban, Chem. Eur. J. 2014, 20, 8929-8933; c) J. Ciesielski, G. Dequirez, P. Retailleau, V. Gandon, P. Dauban, Chem. Eur. J. 2016, 22, 9338-9347.

[22] S. Zhang, Y.-K. Won, C.-N. Ong, H.-M. Shen, Curr. Med. Chem. 2005, 5, 239-249.

[23] P. Skehan, R. Storeng, D. Scudiero, A. Monks, J. McMahon, D. Vistica, J. T. Warren, H. Bokesch, S. Kenney, M. R. Boyd, J. Natl. Cancer Inst. 1990, 82, 1107-1112.

[24] A. Monks, D. Scudiero, P. Skehan, R. Shoemaker, K. Paull, D. Vistica, C. Hose, J. Langley, P. Cronise, A. Vaigro-Wolff, M. Gray-Goodrich, H. Campbell, J. Mayo, M. Boyd, J. Natl. Cancer Inst. 1991, 83, 757766.

[25] C.-M. Sun, W.-J. Syu, M.-J. Don, J.-J. Lu, G.-H. Lee, J. Nat. Prod. 2003, 66, 1175-1180.

[26] C. Chang, P. M. Bahadduri, J. E. Polli, P. W. Swaan, S. Ekins, Drug Metab. Dispos. 2006, 34, 1976-1984.

[27] A. M. Bergman, H. M. Pinedo, I. Talianidis, G. Veerman, W. J. P. Loves, C. L. van der Wilt, G. J. Peters, Br. J. Cancer 2003, 88, 1963-1970.

[28] M. Castaing, A. Loiseau, A. Cornish-Bowden, J. Biosci. 2007, 32, 737-746. 


\section{Legends for schemes and tables:}

Figure 1. Natural guaianolides for the study.

Figure 2. Chemo- and stereoselective late-stage $\mathrm{C}\left(\mathrm{sp}^{3}\right)-\mathrm{H}$ amination.

Scheme 1. Derivatives of natural guaianolides obtained by application of rhodium(II)-catalyzed intermolecular nitrene transfer with $\mathrm{TcesNH}_{2}$.

Scheme 2. Derivatives of natural guaianolides obtained by application of rhodium(II)-catalyzed intermolecular nitrene transfer with $\mathrm{PhsNH}_{2}$.

Scheme 3. Gram-scale reaction and removal of the Pfbs protecting group.

Table 1. In Vitro Antiproliferative Activity against Human Solid Tumor Cell Lines and a Human Fibroblast Cell Line. ${ }^{[a]}$

Table 2. Antiproliferative Activities (GI 50 Values) using the SW1573 and SW1573/Pgp Cell Lines. ${ }^{\text {[a] }}$ 
Table 1.

\begin{tabular}{|c|c|c|c|c|c|c|c|}
\hline Compound & A549 & HBL-100 & $\mathrm{HeLa}$ & SW1573 & $\mathrm{T}-47 \mathrm{D}$ & WiDr & BJ-hTERT \\
\hline Ludartin & $8.9 \pm 1.2$ & $17 \pm 0.1$ & $13 \pm 1.7$ & $10 \pm 2.8$ & $28 \pm 1.5$ & $17 \pm 3.8$ & $\mathrm{Nt}$ \\
\hline Achalensolide & $3.3 \pm \mathbf{0 . 0 3}$ & $6.0 \pm 1.0$ & $5.4 \pm 1.5$ & $4.9 \pm 1.8$ & $18 \pm 1.6$ & $4.5 \pm 0.04$ & $>100$ \\
\hline $\begin{array}{l}\text { 11,13- } \\
\text { Dihydroachalensol } \\
\text { ide }\end{array}$ & $>100$ & $>100$ & $>100$ & $>100$ & $>100$ & $>100$ & $\mathrm{Nt}$ \\
\hline 1 & $1.9 \pm 0.4$ & $1.8 \pm 0.1$ & $2.0 \pm \mathbf{0 . 0 2}$ & $2.0 \pm 0.04$ & $4.7 \pm 0.2$ & $2.7 \pm 0.25$ & $>100$ \\
\hline 3 & $36 \pm 4.8$ & $50 \pm 1.6$ & $14 \pm 2.0$ & $36 \pm 6.9$ & $56 \pm 6.6$ & $47 \pm 2.5$ & $\mathrm{Nt}$ \\
\hline 4 & $>100$ & $>100$ & $>100$ & $>100$ & $>100$ & $>100$ & $\mathrm{Nt}$ \\
\hline 5 & $3.0 \pm 0.5$ & $3.2 \pm 0.5$ & $3.3 \pm 0.4$ & $2.5 \pm 0.3$ & $7.8 \pm 2.0$ & $3.8 \pm 0.8$ & $>100$ \\
\hline 6 & $28 \pm 5.1$ & $22 \pm 4.7$ & $18 \pm 2.3$ & $21 \pm 3.6$ & $41 \pm 3.4$ & $27 \pm 1.2$ & $\mathrm{Nt}$ \\
\hline 7 & $>100$ & $>100$ & $>100$ & $>100$ & $>100$ & $>100$ & $\mathrm{Nt}$ \\
\hline 8 & $5.6 \pm 0.05$ & $13 \pm 3.0$ & $15 \pm 2.0$ & $6.8 \pm 1.4$ & $17 \pm 0.02$ & $12 \pm 2.5$ & $\mathrm{Nt}$ \\
\hline 9 & $>100$ & $>100$ & $>100$ & $>100$ & $>100$ & $>100$ & $\mathrm{Nt}$ \\
\hline Cisplatin & $4.9 \pm 0.2$ & $1.9 \pm 0.2$ & $1.8 \pm 0.5$ & $2.7 \pm 0.4$ & $17 \pm 3.3$ & $23 \pm 4.3$ & $14 \pm 2.4$ \\
\hline
\end{tabular}

[a] Expressed as GI50 and standard deviation. Values are given in $\mu \mathrm{M}$ and determined as means of two to three experiments. Nt.: not tested. 
Table 2.

\begin{tabular}{lllllll}
\hline & \multicolumn{3}{c}{-Verapamil } & & +Verapamil \\
\cline { 2 - 7 } & SW1573 & SW1573/Pgp & Rf & SW1573 & SW1573/Pgp & Rf \\
\hline Achalensolide & $3.1 \pm 0.1$ & $5.1 \pm 0.5$ & 1.6 & $3.7 \pm 0.7$ & $3.5 \pm 0.2$ & 1.0 \\
\hline $\mathbf{1}$ & $1.2 \pm 0.3$ & $1.4 \pm 0.1$ & 1.2 & $0.66 \pm 0.11$ & $1.3 \pm 0.2$ & 2.0 \\
\hline $\mathbf{5}$ & $0.64 \pm 0.08$ & $1.1 \pm 0.1$ & 1.8 & $0.96 \pm 0.11$ & $1.4 \pm 0.1$ & 1.5 \\
\hline Paclitaxel & $1.5 \pm 0.5$ & $196 \pm 53$ & 128 & $1.6 \pm 0.2$ & $4.2 \pm 0.9$ & 2.6 \\
\hline Vinblastine & $0.9 \pm 0.3$ & $2051 \pm 682$ & 2388 & $0.8 \pm 0.2$ & $1.0 \pm 0.5$ & 1.3 \\
\hline
\end{tabular}

[a] Values are given in $\mu \mathrm{M}$ and represent the mean values of at least two independent experiments \pm standard deviation. 


\section{Suggested text for the table of contents:}

Application of rhodium(II)-catalyzed intermolecular nitrene transfers to naturally-occurring guaianolide compounds led to isolate nine new derivatives that possess an amino functional group at $\mathrm{C}-1, \mathrm{C}-2, \mathrm{C}-10, \mathrm{C}-11$ and/or $\mathrm{C}-13$ positions. The relevance of late-stage $\mathrm{C}-\mathrm{H}$ amination strategy in medicinal chemistry is demonstrated by the improved antiproliferative activity of the C-2 aminated analogs of guaianolide products.

\section{Keywords:}

$\mathrm{C}-\mathrm{H}$ amination $\bullet$ Late-stage functionalization $\bullet$ Sesquiterpene lactones $\bullet$ Antiproliferative activity $\bullet$ Nitrene 


\section{Graphics:}

\section{Graphical abstract}

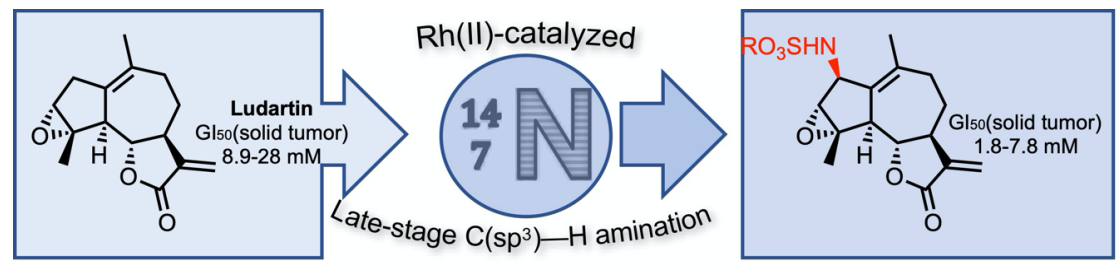


Figure 1

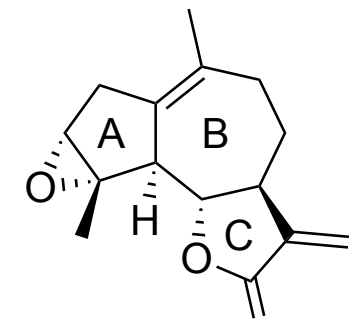

Ludartin $\mathrm{O}$<smiles>C=C1C(=O)O[C@@H]2C[C@H](C)[C@H]3CC(=O)C(C)=C3C[C@H]12</smiles>

Achalensolide 11,13-Dihydroachalensolide

\section{Scheme 1}

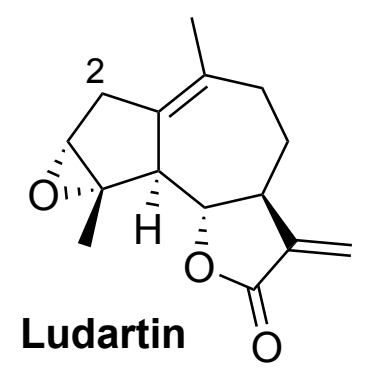

(a)

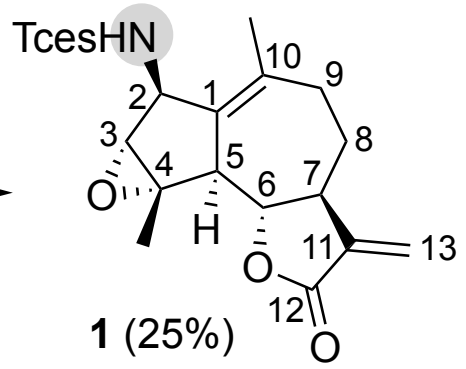<smiles>CC1=C2C[C@@H]3C(=[W])C(=O)O[C@H]3C[C@H](C)[C@@H]2CC1=O</smiles><smiles>[Y9][C@@H]1C(=O)O[C@H]2CC3=C(C)C(=O)C[C@H]3[C@@H](C)C[C@@H]21</smiles>

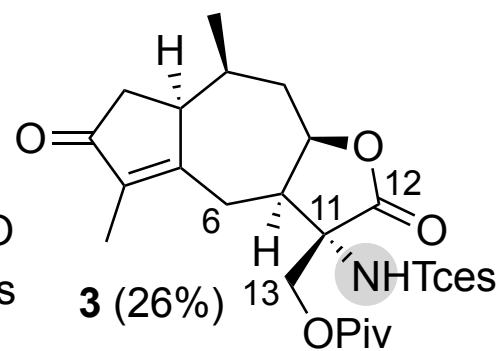<smiles>CC1=C2C[C@H]3[C@H](O)C(=O)[C@@H](C)[C@@H]3C[C@H](C)[C@H]2CC1=O</smiles>

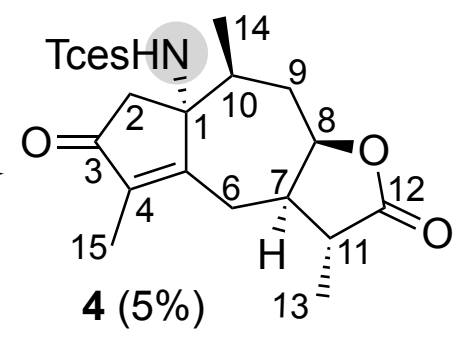
achalensolide

Reaction conditions:

(a) $2 \mathrm{~mol}_{\%} \mathrm{Rh}_{2}(\mathrm{esp})_{2}, 1.2$ equiv. TcesNH $\mathrm{H}_{2}, 2.0$ equiv. Phl(OPiv) $)_{2}$, Benzene, rt 


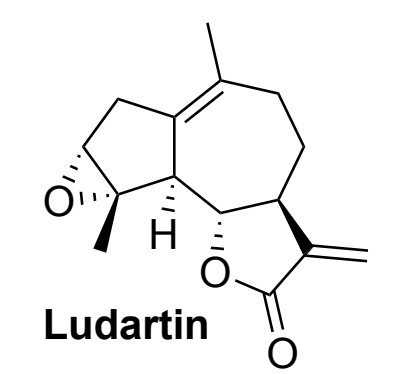

$\stackrel{(a)}{\longrightarrow}$
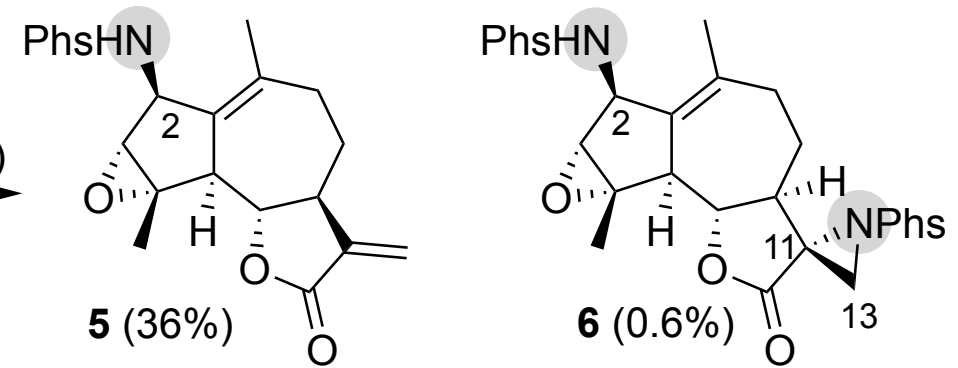<smiles>C=C1C(=O)O[C@H]2C[C@H](C)[C@@H]3CC(=O)C(C)=C3C[C@H]12</smiles>
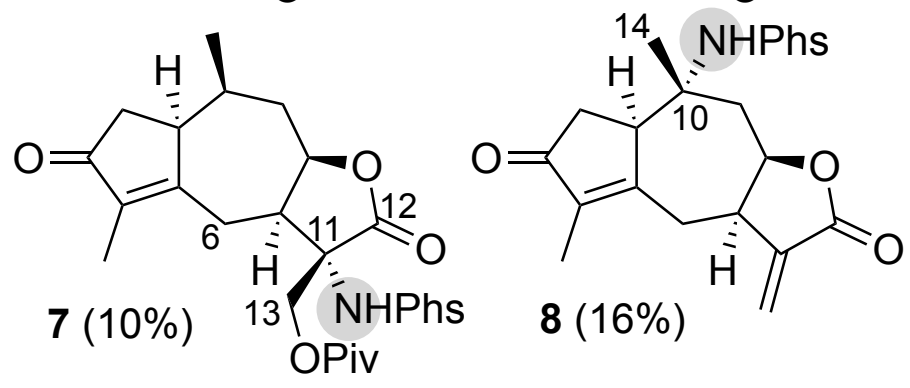

Achalensolide
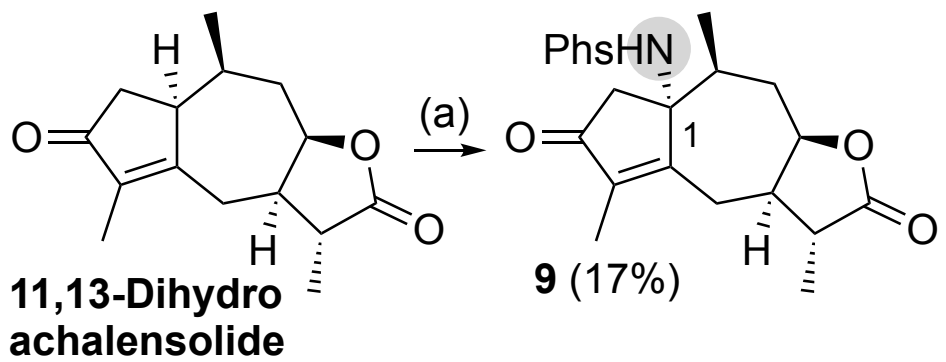

achalensolide

Reaction conditions:

(a) 2 mol\% $\mathrm{Rh}_{2}(\mathrm{esp})_{2}, 1.2$ equiv. $\mathrm{PhsNH}_{2}, 2.0$ equiv. $\mathrm{Phl}(\mathrm{OPiv})_{2}$, Benzene, rt 